\title{
Pelatihan Penulisan Artikel untuk Publikasi E-Jurnal Bagi Researcher Club
}

\author{
Gunsneli Yanti*1, Zainuri², Shanti Wahyuni Megasari3 \\ 1,2,3Program Studi Teknik Sipil, Fakultas Teknik, Universitas Lancang Kuning \\ *e-mail: gusneli@unilak.ac.id ${ }^{1}$,zainuri@ unilak.ac.id ${ }^{2}{ }_{2}$ shanti@ unilak.ac.id $^{3}$
}

\begin{abstract}
Journal is a place for publication of scientific works, the quality and content entirely lies in the written word. Plagiarism can be found because of negligence in writing the references. The purpose of this dedication is to help partners in understanding plagiarism, strategies to make articles using the application of Mendeley and scientific publications by organizing article writing training for members of the Research Club for publication. The method of implementation used was lectures and discussions. The training period lasts for 2 days, starting from the pre-test, material about journal publications, plagiarism, delays, and article writing strategies for e-journals and ending with post-test implementation. The pre-test results obtained an average value of 68,86 (adequate category), whereas for the assessment of the mastery of training material is 85,65 and the post-test is 86,62 both in the excellent category. From the average assessment, it can be proven that the article writing training for publication in e-journals for the Researcher Club is very useful and able to increase knowledge in writing articles for publication in e-journals for trainees.
\end{abstract}

Keywords: articles, e-journals, Mendeley, plagiarism, publications

\begin{abstract}
Abstrak
Jurnal merupakan wadah publikasi karya ilmiah, sepenuhnya mutu dan isi terletak pada hasil karya yang ditulis. Plagiat dapat ditemukan karena kelalaian dalam penulisan daftar pustaka. Tujuan dari pengabdian adalah membantu mitra dalam memahami plagiarism, strategi membuat artikel dengan pemanfaatan aplikasi mendeley serta publikasi ilmiah dengan mengadakan pelatihan penulisan artikel bagi anggota researcher club untuk publikasi. Metode pelaksanaan yang digunakan adalah ceramah, dan diskusi. Waktu pelatihan selama dua hari, dimulai dari pre-test, materi tentang publikasi, plagiat, mendelay, dan strategi menulis artikel untuk e-jurnal serta diakhiri dengan post-test. Hasil pre-test mendapatkan nilai ratarata 68,86 (kategori cukup), sedangkan untuk penilaian terhadap penguasaan materi pelatihan adalah 85,65 dan post-test adalah 86,62 keduanya dalan kategori sangat baik. Dari penilaian rata-rata dapat membuktikan bahwa pelatihan penulisan artikel untuk publikasi pada e-jurnal bagi Researcher Club sangat bermanfaat dan mampu meningkatkan pengetahuan di dalam penulisan artikel untuk publikasi pada e-jurnal bagi peserta pelatihan.
\end{abstract}

Kata kunci: artikel, e-jurnal, mendeley, plagiat, publikasi

\section{PENDAHULUAN}

Researcher Club merupakan kumpulan dari peneliti pemula dari berbagai disiplin ilmu. Sebagai pemula untuk menghasilkan karya-karya berkualitas perlu belajar banyak dalam hal meneliti, serta menulis hasil karya penelitian tersebut dan selayaknya dipublikasikan demi pengembangan suatu karya. Tujuan dari pengabdian ini adalah membantu mitra dalam memahami plagiarism, strategi membuat artikel dengan pemanfaatan aplikasi mendeley serta publikasi ilmiah dengan mengadakan pelatihan penulisan artikel bagi anggota researcher club untuk publikasi.

Pendapat beberapa pakar kemampuan menulis dari opini sampai dengan argumentasi, serta keterampilan bahasa yang digunakan cukup menyulitkan dalam menulis artikel dari hasil penelitian yang dilakukan, menulis menurut beberapa hasil penelitian merupakan keterampilan berbahasa paling tinggi (Anshori, 2005) dan (Cahyani, 2010). Seperti diketahui penulisan artikel ilmiah bertujuan untuk mendesiminasikan pemikiran atau temuan ke masyarakat yang lebih luas salah satu nya melalui e-jurnal sesuai disiplin ilmunya (Mulia \& Suwarno, 2016). Artikel ilmiah merupakan suatu bentuk kontribusi keilmuan pada kemajuan ipteks. Hal yang tidak boleh dilupakan dalam penulisan artikel salah satunya menyesuaikan tulisan terhadap gaya selingkung 
dari jurnal yang dituju. Petunjuk penulisan (template) merupakan panduan dalam mengajukan tulisan (Butsi \& Nasution, 2017).

Jurnal elektronik sebagai wadah publikasi karya ilmiah sepenuhnya mutu dan isi tersebut terletak pada hasil karya yang kemudian ditulis dalam format ilmiah, sistematika penulisan dan menggunakan referensi atau citation manager seperti mendeley. Plagiat dapat ditemukan karena kelalaian seorang penulis dalam penulisan daftar pustaka. Untuk meminimalisirnya maka dapat digunakan Mendeley yang merupakan salah satu aplikasi yang popular saat ini dan merupakan suatu sistem yang bisa melacak sebuah sumber secara otomatis, (Pahmi et al., 2018). Plagiarisme muncul sebagai konsekuensi dari semakin terbukanya informasi melalui internet dan media sosial. Salah satunya untuk mendapatkan informasi yang dibutuhkan, termasuk dalam memperoleh referensi pada penulisan karya ilmiah. Etika copy-paste atau pengutipan sumber informasi belum menjadi hal yang diperhatikan, tidak sedikit yang seenaknya dalam melakukan copy-paste yang berasal dari internet, budaya copy-paste ini seolah sudah menjadi rahasia umum, apabila hal ini terus dibiarkan maka akan semakin meningkatkan budaya plagiarisme (Sahla \& Mukhlisah, 2019).

\section{METODE}

Kegiatan Pengabdian Kepada Masyarakat ini melibatkan mitra yaitu researcher club, dengan jumlah peserta sebanyak 22 orang. Metode pelaksanaan kegiatan Pengabdian Kepada Masyarakat adalah metode ceramah, latihan dan diskusi. Pelatihan dilaksanakan selama 2 (dua) hari kerja yang dimulai dari pukul 09.00 sampai 15.00 WIB.

Penilaian dilakukan terhadap peserta pelatihan dalam menjawab lembar pertanyaan yang diberikan pada pelatihan. Evaluasi yang dilaksanakan meliputi :

a. Penilaian pendahuluan (pre-test), yang dilaksanakan sebagai indikator pengukur pengetahuan peserta terhadap topik yang akan disampaikan sebelum dilakukan pelatihan

b. Penilaian penguasaan materi pelatihan

c. Penilaian akhir (post-test), yang dilaksanakan sebagai indikator terhadap peningkatan pengetahuan peserta terhadap topik yang akan disampaikan setelah dilakukan pelatihan

Penilaian tersebut digunakan untuk membandingkan pengetahuan peserta sebelum dan sesudah pelatihan yang diberikan. Penentuan kategori penilaian (Yanti, et al, 2017) mengacu pada batasan penilaian dalam angka serta kategori yang dipergunakan, mulai dari kategori sangat kurang sampai dengan kategori sangat baik ( tabel 1)

Tabel 1. Nilai dalam angka dan kategori

\begin{tabular}{cc}
\hline Nilai & Kategori \\
\hline Kurang dari 40 & Sangat kurang \\
$\leq 40-<55$ & kurang \\
$\leq 55-<70$ & cukup \\
$\leq 70-<85$ & baik \\
$\leq 85-100$ & sangat baik \\
\hline
\end{tabular}

Bila terjadi peningkatan yang cukup signifikan dapat dikatakan pelatihan yang diberikan memberikan hasil positif sesuai yang diharapkan. Dengan kata lain bukan besarnya nilai yang diperhitungkan tapi peningkatan nilai yang menjadi perhatian utama kegiatan pengabdian kepada masyarakat. 


\section{HASIL DAN PEMBAHASAN}

\subsection{Hasil}

Pelatihan Penulisan Artikel Untuk E-Jurnal pada Pengabdian Kepada Masyarakat ini melibatkan mitra yaitu Researcher Club Kota Pekanbaru. Seperti (Salam, et.al, 2017) pelatihan ini terdiri dari 3 tahapan yaitu diawali terlebih dahulu dengan ujian pendahuluan (pre-test), kemudian penyampaian materi dan latihan terhadap pemahaman materi serta diakhir dengan post-test. Pretest dilakukan sebagai indikator pengukur pemahaman dan pengetahuan peserta terhadap topik yang akan disampaikan sebelum dilakukan pelatihan. Penilaian pendahuluan diberikan dalam bentuk soal multi choice yang harus dijawab oleh peserta pelatihan. Soal yang dibagikan berisi pengetahuan dasar peserta tentang materi pelatihan.

Materi publikasi ilmiah pada jurnal online dalam hal ini menggunakan Open Journal System (OJS). Pada tahapan ini instruktur memberikan penjelasan mengenai apa itu publikasi ilmiah, kemudian materi mengenai Open Journal System (OJS), bagaimana Register dan cara submit artikel dengan menggunakan Open Journal System (OJS). Isi artikel ditulis berdasarkan template yang ada pada jurnal yang akan dituju. Panduan penulisan biasanya dilengkapi dengan deskripsi huruf, spasi, dan informasi lainnya yang berhubungan dengan penulisan artikel. Artikel yang sudah memenuhi petunjuk penulisan (template artikel, kemudian dikirimkan secara daring dengan Online Submission System di portal e-Journal) setelah mendaftarkan sebagai author di bagian "Register". Langkah untuk melakukan submit manuskrip secara daring dapat dilihat di petunjuk submit manuskrip/ artikel secara online.

Teori tentang plagiarm, materi yang diberikan terdiri dari pengertian plagiat, alat bantu yang digunakan untuk melakukan pengecekan tingkat plagiat dalam hal ini menggunakan turnitin lihat gambar 1, kemudian teknik menulis untuk menghindari plagiarisme diantaranya melakukan kutipan tidak langsung. Mengutip secara tidak langsung dapat diwujudkan dalam bentuk yakni membuat parafrasa, meringkas atau menyusun kesimpulan. Parafrasa merupakan salah satu cara meminjam gagasan/ide dari sebuah sumber tanpa menjadi plagiat. Menurut Kamus Oxford Advanced Leaner's Dictionary, parafrasa merupakan "cara mengekspresikan apa yang telah ditulis dan dikatakan oleh orang lain dengan menggunakan kata-kata yang berbeda agar membuatnya lebih mudah untuk dimengerti."
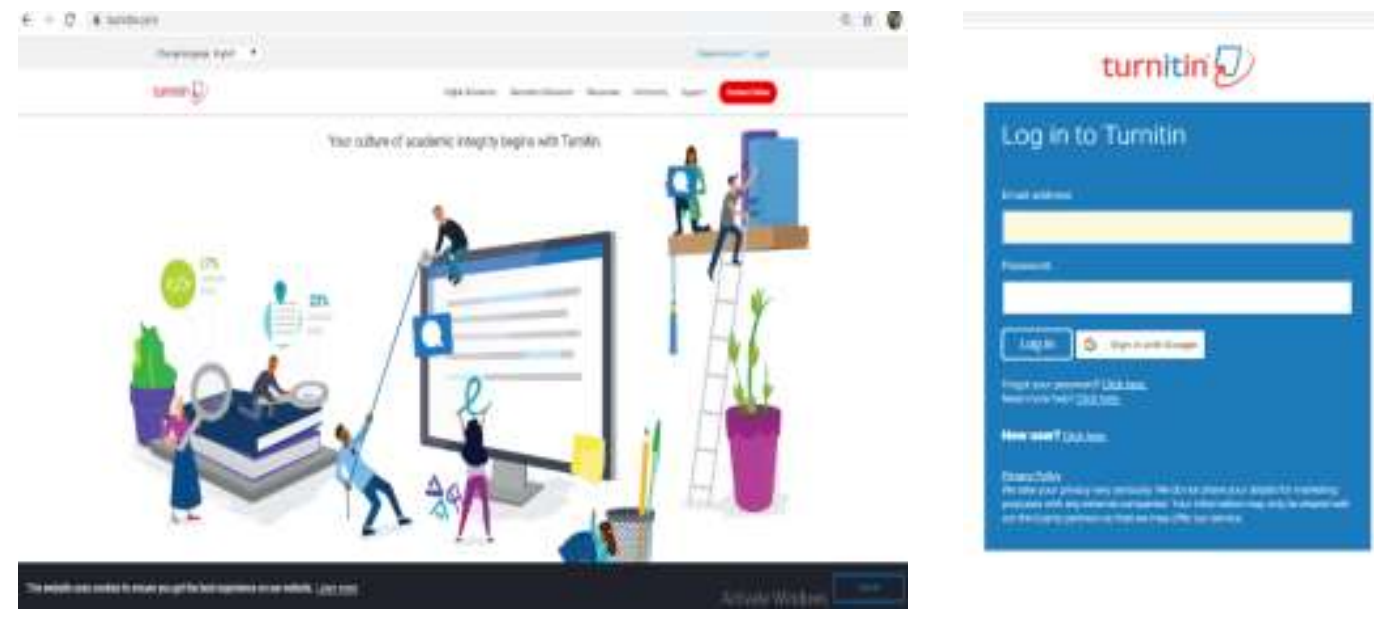

Gambar 1. Pengecekan plagiat dengan Turnitin

Pada pelaksanaan pelatihan di ruangan peserta penggunakan laptop untuk memudahkan dalam pelaksanaan pelatihan. Selama pelaksanaan pelatihan peserta terlihat semangat, keingintahuan dan keaktifan dari para peserta dalam mengikuti pelatihan. Pada gambar 2 terlihat instruktur memberikan materi pada pelatihan penulisan artikel untuk e-jurnal . 


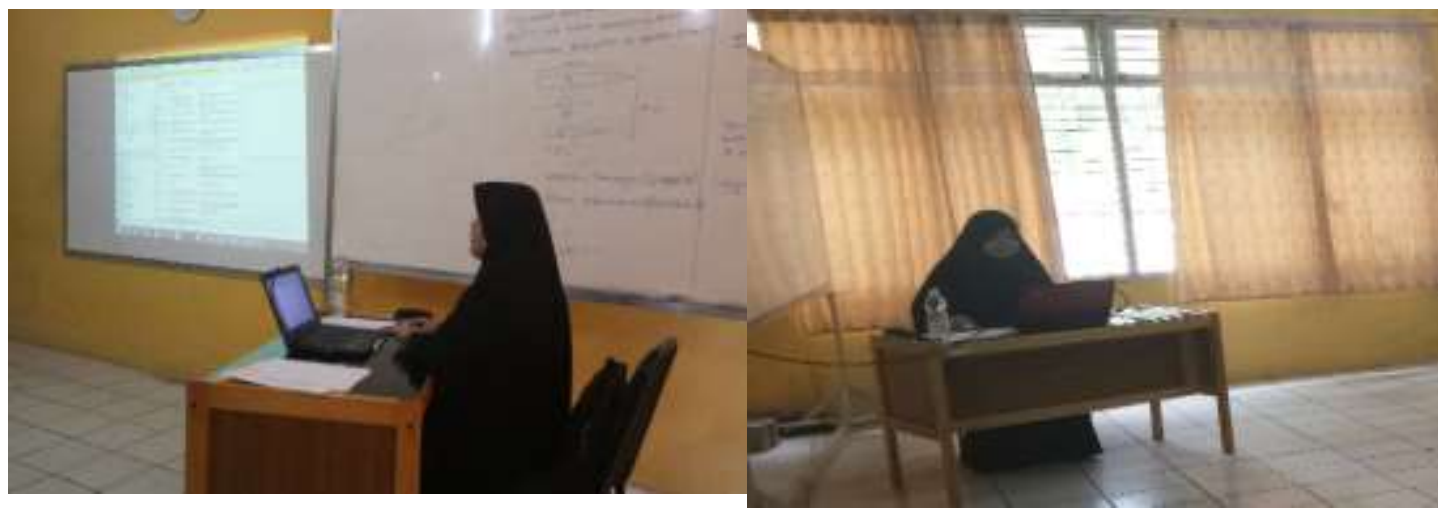

Gambar 2. Instruktur memberikan materi pelatihan

Materi Mendeley yang diberikan yaitu cara mengoperasikan mendeley dan memasukkan referensi, menyusun daftar pustaka dan gaya sitasi . Gambar 3 bisa dilihat bahwa Microsoft word sudah terhubung dengan mendeley.

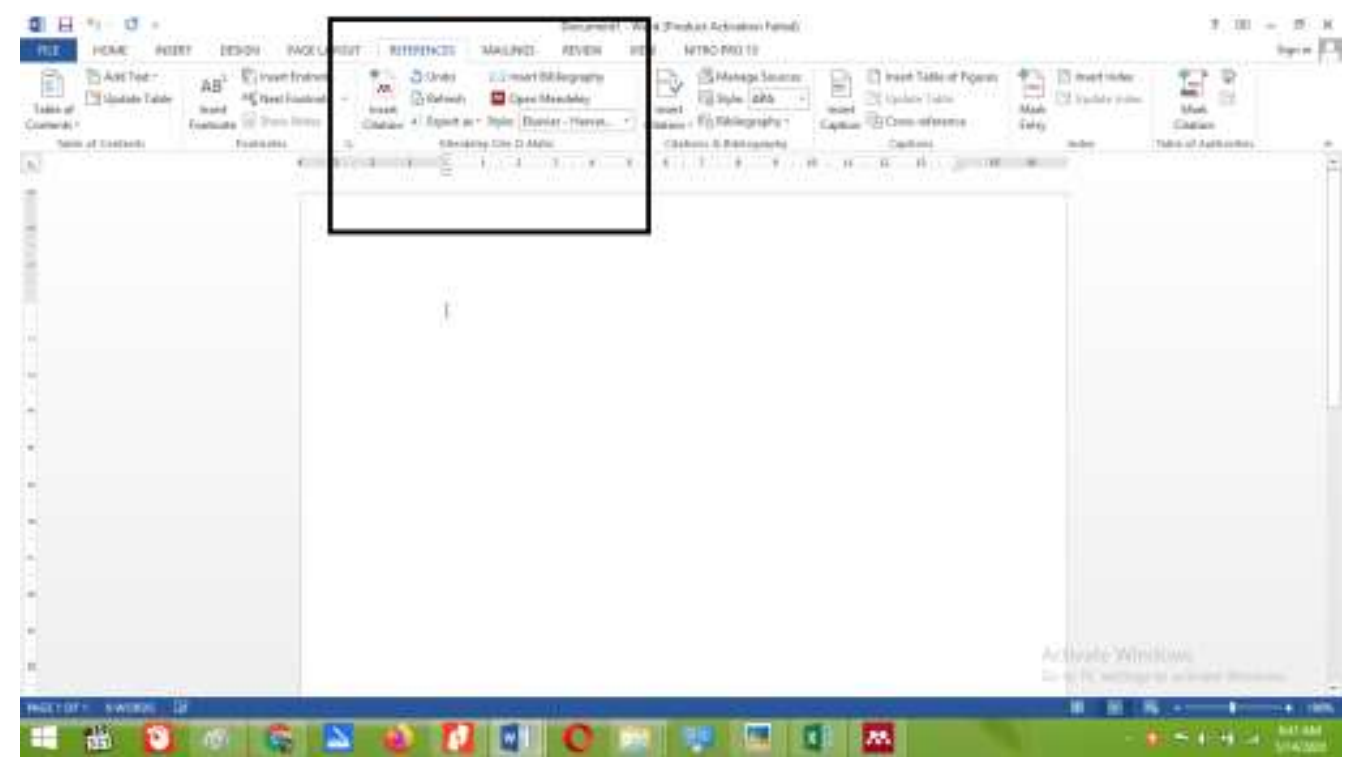

Gambar 3. Tampilan Mendeley pada Ms.Word

Kiat dan strategi menulis artikel di e-jurnal juga diberikan pada pelatihan ini, dimana pada prinsipnya penyusunan artikel ilmiah yang akan disajikan dalam jurnal ilmiah relatif sama dengan makalah ilmiah yang akan disajikan dalam forum seminar. Hal penting yang perlu diperhatikan focus and scope jurnal yang akan dituju. Penting diperhatikan agar naskah yang telah disusun tidak salah alamat. Terdapat pula jurnal yang khusus menyajikan hasil-hasil penelitian semata, tetapi ada pula jurnal yang mewadahi hasil-hasil pernelitian maupun pemikiran-pemikiran konseptual. Sedangkan dilihat dari derajat akreditasinya jurnal ilmiah dapat dikategorikan menjadi jurnal ilmiah terakreditasi dan jurnal ilmiah tidak terakreditasi. Petunjuk bagi penulis merupakan panduan dalam mengajukan tulisan (Butsi \& Nasution, 2017). Selama pelaksanaan pelatihan peserta terlihat semangat, keingintahuan dan keaktifan dari para peserta dalam mengikuti pelatihan, pada sesi ini peserta sangat antusias dan serius dalam mengikuti materi yang diberikan seperti terlihat pada gambar 4. Setelah penyampaian materi selesai maka dilaksanakan evaluasi mengenai materi yang diberikan. Sebelum evaluasi dilaksanakan masih ada peserta yang bertanya mengenai materi yang kurang jelas. Peserta pelatihan menyatakan bahwa materi pelatihan yang agak rumit adalah di materi plagiarisme. 

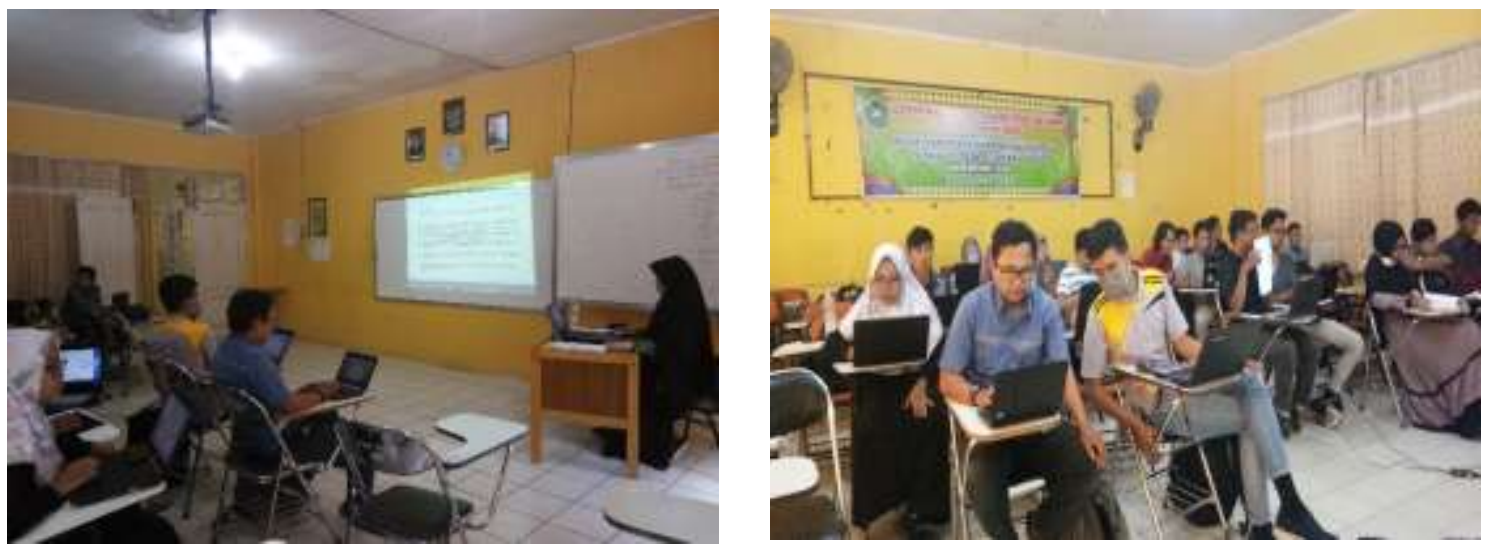

Gambar 4. Suasana ruang kelas pada saat pelatihan

Sesi terakhir dihari ke dua ditutup dengan (post test) terhadap kemampuan peserta pelatihan untuk mengetahui sejauh mana materi pelatihan dapat diserap oleh peserta pelatihan. Sesi kelima, merupakan sesi terakhir ditutup dengan (post test) terhadap kemampuan peserta pelatihan untuk mengetahui sejauh mana materi pelatihan dapat diserap oleh peserta pelatihan. Evaluasi diberikan dalam bentuk pertanyaan- pertanyaan yang harus dijawab dengan benar oleh peserta pelatihan dalam bentuk ujian tertulis (post-test). Acara pelatihan ditutup dengan foto bersama instruktur dan peserta pelatihan (gambar 5)
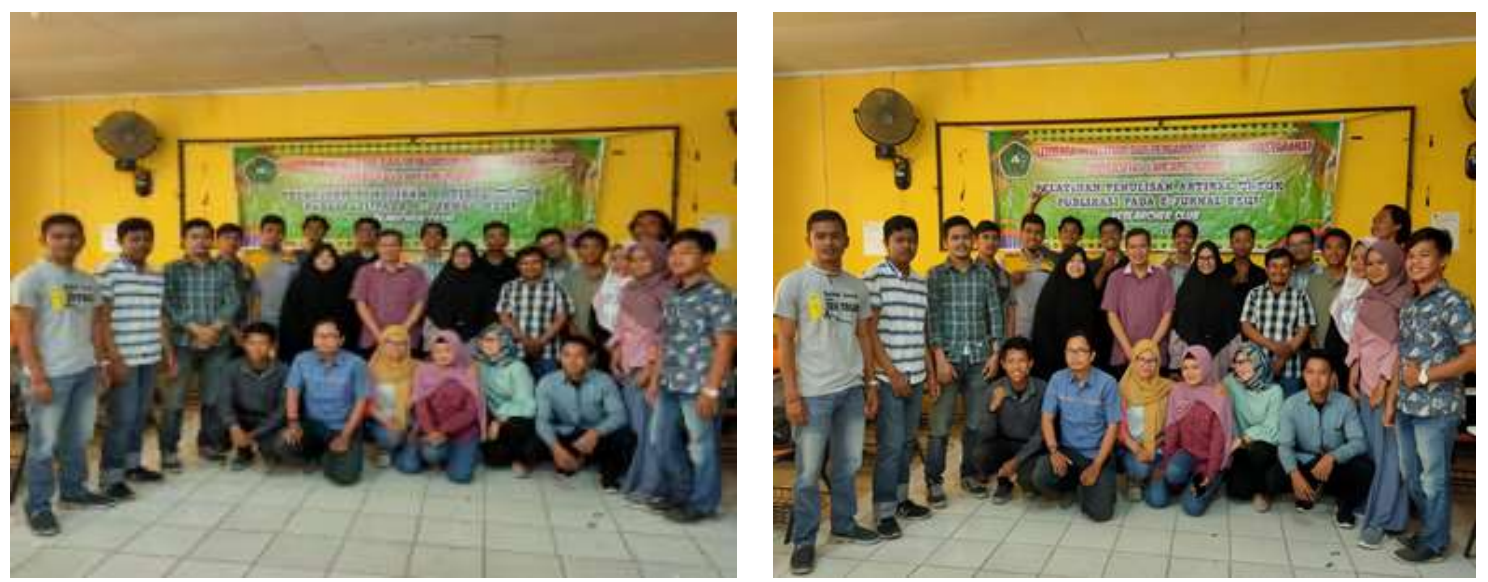

Gambar 5. Foto bersama instruktur dan peserta

\subsection{Pembahasan}

Evaluasi yang dilakukan pada pelatihan penulisan artikel untuk publikasi pada e-jurnal ini sebanyak 3 (tiga) tahapan, yaitu :

a. Penilaian pendahuluan (pre-test)

Penilaian pendahuluan (Pre-test) yang dilaksanakan sebagai indikator pengukur pengetahuan peserta terhadap topik yang akan disampaikan sebelum dilakukan pelatihan, dalam hal ini ada 3 materi yang akan dibahas pada penulisan artikel untuk publikasi pada e-jurnal yaitu publikasi, plagiarism, Mendeley.

Mengacu artikel yang ada (Yanti, et al, 2019) melakukan batasan penilaian melalui angka terhadap penilaian peserta pelatihan. Penilaian pendahuluan (pre-test) kepada peserta pelatihan, hasil ujian dapat dilihat pada tabel 2. 
Tabel 2. Penilaian rata-rata pre-test peserta pelatihan

\begin{tabular}{llcl}
\hline No & Materi & Nilai rata-rata peserta & Kategori penilaian \\
\hline 1 & Publikasi & 72,73 & Baik \\
2 & Plagiat & 65,91 & Cukup \\
3 & Mendeley & 67,95 & Cukup \\
\hline & Rata-rata & 68,86 & Cukup \\
\hline
\end{tabular}

Dari hasil penilaian pendahuluan (pre-test) terhadap peserta pelatihan didapat nilai ratarata adalah 68,86. Dengan nilai rata-rata tersebut diketahui bahwa pengetahuan peserta pelatihan dalam kategori cukup $(\leq 55-<70)$. Dimana persentase hasil perolehan nilai $50 \%$ atau 11 peserta mendapatkan hasil cukup dan $50 \%$ (11 peserta) pelatihan lainnya pada kategori baik. Namun dari hasil pretest dapat di ketahui bahwa dari 3 (tiga) materi yang terdapat pada soal pretest (gambar 6) yaitu :

1) materi publikasi diketahu rata-rata 72,73 dalam kategori baik

2) materi plagiarism rata-rata nilainya 65,91 dalam kategori cukup

3) materi mendeley rata-rata nilainya 67,95 dalam kategori cukup

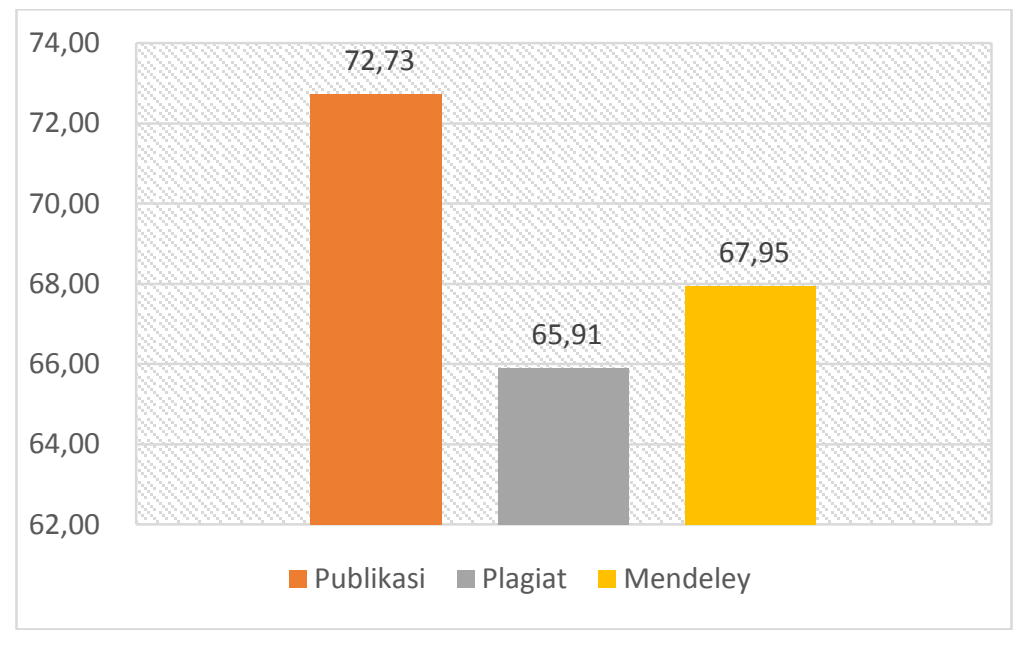

Gambar 6. Hasil penilaian rata -rata pretest peserta pelatihan

b. Penilaian terhadap materi pelatihan.

Pada tahapan ini instruktur memberikan penilaian masing masing bahsan yaitu plagiat, mendelaey dan publikasi. Penilaian diberikan secara individual terhadap masing-masing peserta pelatihan. Aspek dinilai adalah :

1). Materi Plagiat, bobot nilai 30

2). Materi Mendeley, bobot nilai 30

3). Materi Publikasi, bobot nilai 40

Setelah dilakukan penilaian terhadap penguasaan materi publikasi, plagiarisme dan mendeley peserta pelatihan, (tabel 3).

Tabel 3. Penilaian rata-rata penguasaan materi peserta pelatihan

\begin{tabular}{llcl}
\hline No & Materi & Nilai rata-rata peserta & Kategori penilaian \\
\hline 1 & Publikasi & 88,07 & Sangat Baik \\
2 & Plagiat & 82,84 & Baik \\
3 & Mendeley & 85,23 & Sangat Baik \\
\hline & Rata-rata & 85,65 & Sangat Baik \\
\hline
\end{tabular}


Penilaian rata-rata permateri terhadap peserta pelatihan didapat nilai adalah sebesar 85,65. Dengan hasil rata-rata tersebut dapat dikatakan bahwa pemahaman peserta pelatihan terhadap penguasaan materi yang diberikan dalam kategori sangat baik $(\leq 85-100)$. Dimana persentase hasil perolehan nilai rata-rata untuk peserta pelatihan adalah sebagai berikut :

1) Sepuluh (10) peserta pelatihan atau $45,45 \%$ kategori sangat baik dengan nilai diatas 85 untuk penilaian penguasaan materi pada pelatihan.

2) Dua belas orang peserta pelatihan (54,54 \%) kategori baik untuk penilaian penguasaan materi pada pelatihan.

Rata-rata hasil yang didapat dari penguasaan materi selama pelatihan dapat dilihat pada gambar 7, persentase hasil perolehan nilai rata-rata dan kategori untuk peserta pelatihan sebagai berikut :

1) materi publikasi rata-rata 88,07 dalam kategori sangat baik

2) materi plagiarism rata-rata nilainya 82,84 dalam kategori baik

3) materi mendeley rata-rata nilainya 85,23 dalam kategori sangat baik

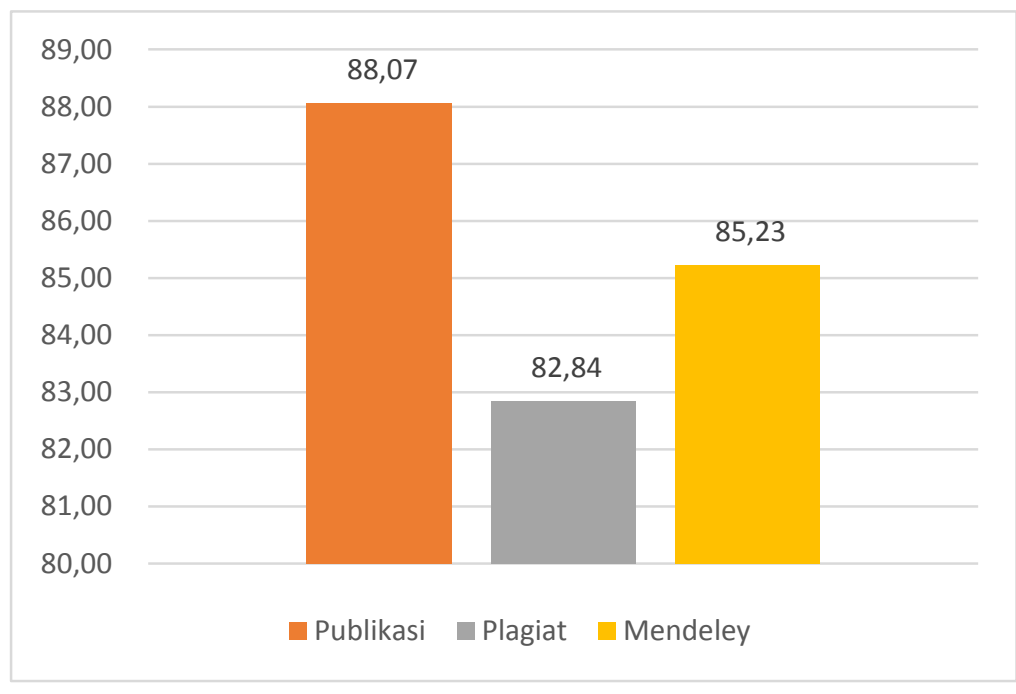

Gambar 7. Hasil penilaian rata -rata penguasaan materi peserta pelatihan

c. Penilaian akhir (post-test)

Pada sesi terakhir dilaksanakan penilaian akhir (post-test), yang dilaksanakan sebagai indikator terhadap peningkatan pengetahuan peserta terhadap topik yang telah disampaikan setelah dilakukan pelatihan. Setelah dilakukan penilaian akhir (post-test) terhadap peserta pelatihan diperoleh nilai rata-rata adalah 86,62 lihat tabel 4

Tabel 4. Penilaian akhir (post-test) peserta

\begin{tabular}{llcl}
\hline No & Materi & Nilai rata-rata peserta & Kategori penilaian \\
\hline 1 & Publikasi & 89,39 & Sangat Baik \\
2 & Plagiat & 83,86 & Baik \\
3 & Mendeley & 86,59 & Sangat Baik \\
\hline & Rata-rata & 86,62 & Sangat Baik \\
\hline
\end{tabular}

Dengan nilai rata-rata post-test dapat dikatakan bahwa pemahaman peserta pelatihan terhadap materi yang diberikan mengalami peningkatan dari kategori pre -test adalah cukup (dengan rata-rata nilai 68,86) menjadi 86,62 dalam kategori sangat baik $(\leq 85-100)$. Dimana 
persentase hasil perolehan nilai masing-masing peserta pelatihan adalah sebagai berikut (gambar 7)

1) Lima belas peserta pelatihan $(68,18 \%)$ dengan kategori sangat baik untuk penilaian Post-test pada pelatihan.

2) Sembilan peserta pelatihan atau 31,81\% dengan kategori baik untuk penilaian Post-test pada pelatihan.

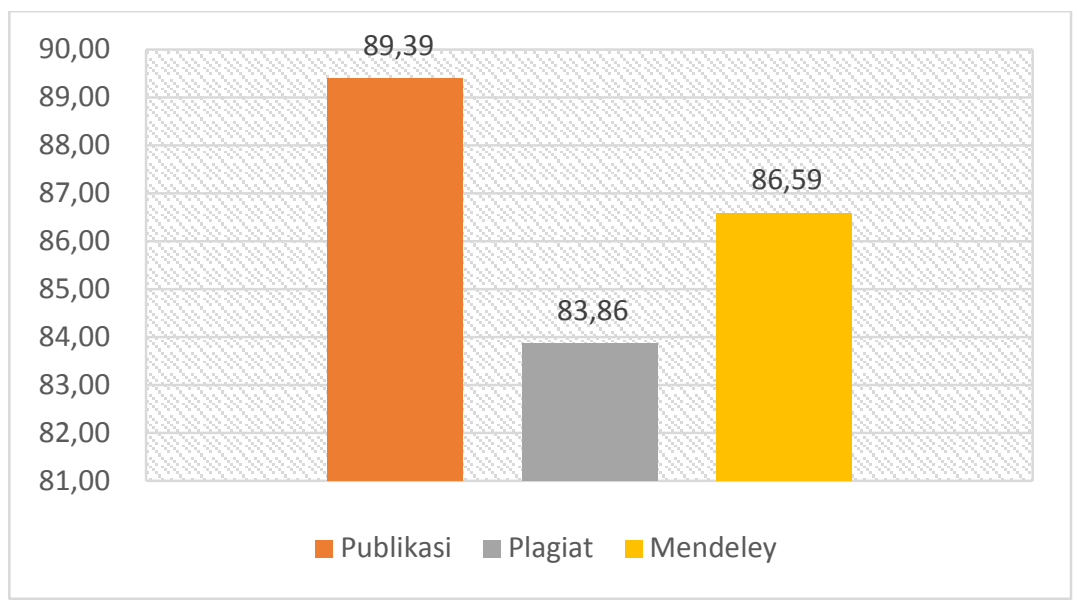

Gambar 8. Hasil penilaian rata -rata post-test peserta pelatihan

Sejalan dengan (Damayanti, et.al, 2017) dan (Effendy, 2016) penggunaan metode pretest dan post-test dapat menjadi indikator untuk menetukan apakah terjadi peningkatan pemahaman setelah dilakukannya pelatihan. Rekapitulasi penilaian yang diperoleh peserta pelatihan dari ketiga tahapan evaluasi dapat dilihat dalam gambar 9.

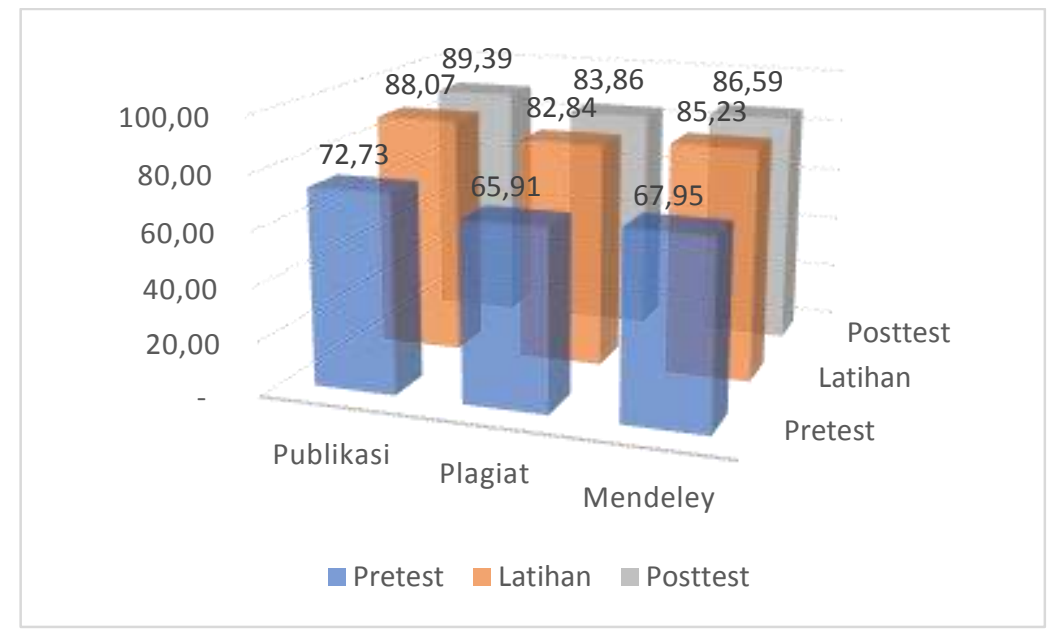

Gambar 9. Rekapitulasi penilaian peserta pelatihan

Berdasarkan pada hasil penilaian tersebut, membuktikan bahwa pelatihan penulisan artikel untuk publikasi pada e-jurnal sangat bermanfaat dan mampu meningkatkan pengetahuan, pemahaman, peserta pelatihan. Sejalan dengan (Yusdita \& Utomo, 2019) perlu diperhatikan untuk pelaksanaan pengabdian mendatang yang sejenis diperlukan laptop, dan koneksi internet yang mendukung agar kegiatan dapat berjalan dengan lancar. 


\section{KESIMPULAN}

Pelatihan penulisan artikel untuk publikasi pada e-jurnal bagi Researcher Club mulai dari awal sampai akhir pelatihan, diperoleh kesimpulan sebagai berikut:

1) Penilaian pendahuluan (pre-test) terhadap peserta pelatihan didapat nilai rata-rata adalah 68,86 dalam kategori cukup dan Penilaian akhir (post-test) diperoleh rata-rata nilai sebesar 86,62 dalam kategori sangat baik, ini membuktikan bahwa pelatihan penulisan artikel untuk publikasi pada e-jurnal mampu meningkatkan pengetahuan

2) Penilaian terhadap pemahaman terhadap materi pelatihan, peserta pelatihan diperoleh ratarata nilai sebesar 85,65 dalam kategori sangat baik mengenai pengetahuan, pemahaman pelatihan penulisan artikel untuk publikasi pada e-jurnal.

\section{UCAPAN TERIMA KASIH}

Penulis mengucapkan terima kasih kepada Lembaga Penetian dan Pengabdian Masyarakat, Universitas Lancang Kuning yang telah memberi dukungan financial terhadap pengabdian ini.

\section{DAFTAR PUSTAKA}

Anshori, D. S. (2005). Peningkatan Kemampuan Menulis Mahasiswa Melalui Model Workshop Dalam Perkuliahan Kepenulisan Pada Program Non Kependidikan Jurusan Pendidikan Bahasa dan Sastra Indonesia FPBS UPI.

Butsi, F. I., \& Nasution, A. (2017). Pelatihan tips dan trik submit artikel ilmiah di jurnal berbasis online. Amaliyah: Jurnal Pengabdian Kepada Masyarakat, 1(1), 49-51.

Cahyani, I. (2010). Peningkatan Kemampuan Menulis Makalah Melalui Model Pembelajaran Berbasis Penelitian pada Mata Kuliah Umum Bahasa Indonesia. Sosiohumanika, 3(2), 175192.

Damayanti, N. A., Pusparini, M., Djannatun, T., \& Ferlianti, R. (2017). Metode Pre-Test dan PostTest sebagai Salah Satu Alat Ukur Keberhasilan Kegiatan Penyuluhan Kesehatan Tentang Tuberkulosis di Kelurahan Utan Panjang, Jakarta Pusat. Prosiding SNaPP2017 Kesehatan, $144-150$.

Effendy, I. (2016). Pengaruh Pemberian Pre-test dan Post-test terhadap Hasil Belajar Mata Diklat HDW.DEV.100.2.A pada Siswa SMK Negeri 2 Lubuk Basung. Volt, 1(2), 81-88.

Mulia, D. S., \& Suwarno. (2016). PTK (Penelitian Tindakan Kelas) dengan Pembelajaran Berbasis Kearifan Lokal dan Penulisan Artikel Ilmiah di SD Negeri Kalisube, Banyumas. Khazanah Pendidikan, $\operatorname{IX}(2)$.

Pahmi, P., Ardiya, A., Syahfutra, W., Wibowo, A. P., Niah, S., \& Febtiningsih, P. (2018). Pelatihan Penggunaan Mendeley untuk Referensi dalam Menulis Karya Ilmiah bagi Guru SMA Handayani Pekanbaru. Pengabdian Untuk Mu NegeRI, 2(2), 35-39.

Sahla, W. A., \& Mukhlisah, N. (2019). IbM-Pelatihan Teknik Penulisan Parafrase. Jurnal Impact: Implementation and Action, 1(2), 162-168.

Salam, R., Akhyar, M., Tayeb, A. M., \& Niswaty, R. (2017). Peningkatan Kualitas Publikasi Ilmiah Mahasiswa dalam Menunjang Daya Saing Perguruan Tinggi. Jurnal Office, 3(1).

Yanti, G., Megasari, S. W., \& Zainuri, Z. (2017). Analisis Pengaruh Pelatihan Teknologi Penyondiran pada Usaha Mikro Konstruksi di Kota Pekanbaru. Siklus : Jurnal Teknik Sipil, $3(1), 39-48$.

Yanti, G., Zainuri, Z., \& Megasari, S. W. (2019). Pelatihan Penjadwalan dengan Ms Project bagi Penyedia Jasa Konstruksi di Kota Pekanbaru. Dinamisia, 3, 125-134.

Yusdita, E. E., \& Utomo, S. W. (2019). Pelatihan Pemanfaatan Mendeley Sebagai Reference Tool Pada Artikel Ilmiah Mahasiswa Pendidikan Akuntansi Unipma. Abdinus, 3(1), 36-46. https://doi.org/10.29407/ja.v3i1.13525 